\title{
Habent sua fata libelli (= Decisiones)
}

\author{
Marko ILE Ǐ $I \check{C}$
}

\section{Audiatur et altera pars}

The case-law of the European Court of Justice (hereinafter the "ECJ") undoubtedly has a significant influence on the judicial (as well as legislative) activity of member states. Its decisions are perceived with different feelings and cause different reactions. By reactions in this context, I do not mean those of the parties who are directly concerned by a judgment, i.e. member states, European institutions, or the persons who are involved either directly in the procedure before the ECJ or indirectly through a national judicial procedure where the national court refers a preliminary ruling to the ECJ. Indeed, their reactions are also interesting; typical, above all, are the reactions to procedures against member states who are obliged to respect decisions on the basis of Article 10 of the EC Treaty.

In this article, I would like to mention some opinions expressed by the academic community in the course of reactions to decisions of the ECJ. Taking into account that I have been kindly invited to comment on some questions about our case-law in the area of labour law, I would like to take this opportunity to limit my presentation to the caselaw which has recently attracted significant attention in terms of theory and which will be a "continued" in the case-law.

Probably you have already guessed that I will speak about the challenges which have been posed by the judgment of the ECJ in the Mangold case, ${ }^{1}$ which has already been mentioned today. It goes without saying that I can only comment on my own behalf and not on that of the ECJ. And the fact that I was a member of the chamber which decided the case in no way means that I would reveal anything that could violate the judge's oath of confidentiality.

Do not get me wrong, I am not commenting on this judgment because I am offended. Quite the opposite is true: the judgment is a confirmation of the statement that the ECJ is an important Impulsgeber (impulse giver) (also) in the area of labour law. And finally, such a vivid response in the literature ${ }^{2}$ is sufficient proof of this.

1 C-144/05, 22.11.2005.

2 My research has found more than 50 published articles. Only in the small country of Slovenia two articles on this case were recently published. Korpič Horvat: Diskriminacija pri zaposlovanju zaradi starosti, in. Delavci in delodajalci, 2-3/2007, p. 313-328; Kresal: Prepoved diskriminacije na področju dela v luči prakse Sodišča ES, in: Prepoved diskriminacije, Ljubljana 2007, p. 45-66. 
I consider it important to stress that the ECJ takes account with all due seriousness of the arguments of the parties participating in the procedure and less seriously of the opinions of doctrine, and that it is sensitive to critics, although such criticism is sometimes expressed in quite an unusual way. Thus it has been written about the above mentioned judgment that it was "surprenant (surprising)", 3 "unconvincing", 4 "mystérieux (mysterious)", 5 and also that it ranged "de l'apostasie à l'hérésie (from apostasy to heresy)", 6 that it was a "horreur juridique (legal horror)", 7 "Missbrauch (misuse)", 8 and, of course, "ein Stück aus dem Tollhaus (a piece from the madhouse)"9, etc., etc.

And my intention is, of course, not to defend the correct solution of the judgment. However, I believe that in analysing the commentaries on the judgment in the Mangold case, it is possible to ascertain the impulses that may, with the common efforts of national and European legislators as well as the legal profession, contribute to further developments of European (labour) law.

\section{Quod capita tod sententiae}

The judgment in the Mangold case contains a judicial assessment of numerous legal questions, some of which exceed the area of labour law. It seems that some commentators find in that judgment opinions which can hardly result from its usual reading. A superficial overview of the positive and the negative commentaries on the judgment shows that the latter take precedence; however, I think it important that the discussion produced several new ideas.

Considering that today's discussion does not leave room for a detailed analysis of open questions, I would only like to enumerate them. The greater focus will be on the most sensitive question that largely concerns the development of labour law.

1. Is the new general principle of the prohibition of discrimination on the rise?

3 Muir, La jurisprudence de la Cour de justice et du Tribunal de première instance. Chronique des arrêts. Arrêt Werner Mangold c. Rüdiger Helm, "Mangold", Revue du droit de l'Union européenne $2006 \mathrm{n}^{\mathrm{o}} 2$ p. $466,470$.

4 Riesenhuber, Case Note ECJ - Mangold, European Review of Contract Law 2007 Vol.3 No.1 p.62, 66.

5 Dubos, La Cour de justice, le renvoi préjudiciel, l'invocabilité des directives : de l'apostasie à l'hérésie ?, au sujet de : CJCE, 22 novembre 2005, aff. C-144/04, in : La semaine juridique, édition générale, 28 juin 2006, n 26, II-10107, p. 1293, 1297.

6 Dubos, La semaine juridique 2006, p. 1293.

7 Dubos, La semaine juridique 2006, p. 1293, 1297.

8 Hunold, Altersbefristungen nach $\S 14$ III TzBfG - Missbrauch des EuGH, NJW-Editorial, Heft $34 / 2005$, p. III

9 Bauer, Ein Stück aus dem Tollhaus: Altersbefristung und der EuGH, NZA 2005, p. 800. 
This principle may develop in the direction of a general principle that may have an important influence on today's understanding of the prohibition of discrimination in the area of labour.

In para. 75 of the Mangold judgment, where the principle of the prohibition of discrimination has been upgraded to the level of a general Community principle deriving from "various international instruments and [found] in the constitutional traditions common to the Member States" (para. 74), the ECJ opened an important discussion about the relation between Article 13 of the EC Treaty and the relevant secondary legislation. This is of particular interest because the prohibition of discrimination is much more unequivocal in some areas, but the ECJ has not yet declared it a general principle. 10

This issue is not only relevant for labour law, but has a much broader impact. It is a problem of the application of "constitutional traditions which are common to member states", which are recognised in primary legislation only in Article 6(2) of the Treaty on European Union and, in a slightly different version, also in Article 288(2) of the EC Treaty. And, at least implicitly, as some commentators point out, it concerns an issue of the Fundamental Rights Charter as a legal source.

Discussion about the impact of this principle is in progress. The ECJ will soon deal with a similar question in the pending case of Palacios de la Villa, ${ }^{11}$ where the Advocate General has already delivered his opinion. ${ }^{12}$

The other open questions I at least wish to address are the following:

2. Do Directives cause a horizontal effect?

3. Are there horizontal effects of Directives?

4. What might be other hypothetical preliminary questions?

\section{Nemo iudex in propria causa}

As mentioned above, as a judge of the ECJ, I have no intention to assess particular solutions put forward in the Mangold judgment. Concluding, I would like to remark that the process of ECJ adjudication, involving 27 judges and the obligation to take account of the same number of legal cultures (or more) when interpreting Community law, is not an easy task. This diversity of approaches can also be felt as regards the wording of judgments, which are, however, not always as clear as one might wish. Yet judgments

10 In the latest edition of his book on this issue, Prof. Tridimas does not take a firmer stand, despite the fact that he refers to the judgment in the Mangold case. Tridimas: The General Principles of EU Law, Oxford 2006, p. 68, note 58.

11 C-411/05.

12 15.12.2007. 
have a meaning for the future. In the Mangold case, the ECJ has announced an important development of labour law.

The fact that faith in a judgment sometimes opens a "story without an end" can be illustrated by events which followed famous judgments, for example in the Defrenne case $^{13}$ of the 1970s on the prohibition of discrimination on the basis of sex concerning salaries of Belgian stewardesses. Although the Belgian legislator tried to compensate for injustices of the past, it did not do so with sufficient diligence, so that this issue was brought before the ECJ, which decided it with the judgment in the Jonkman case. ${ }^{14}$

Isn't this sufficient proof that my motto of today is justified? 


\title{
The European Court of Justice, Labour Law and ILO Standards
}

\author{
Brian BERCUSSON
}

\section{Summary}

Two questions are addressed in this paper: (1) how much does, or will, the ECJ in exercising its jurisdiction in the field of labour law look to international standards; (2) how far does, or will, the ECJ seek to go further or provide less?

The paper reviews the sources from which the ECJ has drawn in exercising its labour law jurisdiction include the Treaties, EU secondary legislation and the general principles of the EU legal order.

The Preamble to the Community Charter of the Fundamental Social Rights of Workers of 1989 refers to" inspiration... drawn from the Conventions of the ILO". The Preamble to the EU Charter of Fundamental Rights 2000 reaffirms "...rights as they result, in particular, from the... international obligations common to the Member States". The absence of an explicit reference in the EU Charter to ILO labour standards is notable.

The European Court of Justice states that fundamental rights form an integral part of the general principles of law and international treaties can supply guidelines. The ECJ finally cited the EU Charter in Case C-540/03, European Parliament v. Council, decided 27 June 2006. While not legally binding itself, the Charter reaffirms rights which are legally binding due to their provenance from other sources which are recognised by Community law as legally binding sources, including "international obligations common to the Member States", of which ILO Conventions are a prime example. In Case C438/05, Viking, Advocate General Maduro concluded: “...the rights to associate and to collective action are of a fundamental character within the Community legal order, as the Charter of Fundamental Rights of the European Union reaffirms". In Case C341/05, Laval, Advocate General Mengozzi, cites Article 28 of the EU Charter and concludes that "the right to resort to collective action to defend trade union members' interests is a fundamental right. It is... a general principle of Community law, within the meaning of Article 6(2) EU. That right must therefore be protected in the Community".

Two examples to illustrate the use of ILO standards in EU secondary legislation: the Directives on public procurement, and the Services Directive.

On the matter of substance, the potential use of ILO standards as sources of EU law may be illustrated two recent developments in the USA and Canada.

In the USA, an agreement was reached in May 2007 between the administration of President George Bush and the Congress on bilateral trade agreements to include the 